\title{
Abstract
}

\section{Bacterial Contamination of Intensive Care Units, Sana'a City, Yemen, 2019}

Mohammed Al Amad ${ }^{1}$, MD; Intesar Abdulsalam Al Shargabi ${ }^{2}$; Samar Nasher ${ }^{1}$, MD; Sami Ahmed Al-Haidari ${ }^{3}$; Riham Al-Dubaiee ${ }^{1}$; Suaad Ameen Moghalles ${ }^{1}$; Khaled Abdullah Al Moayad ${ }^{3}$

\footnotetext{
${ }^{1}$ Yemen Field Epidemiology Training Program, Sana'a, Yemen

${ }^{2}$ National Center of Public Health Laboratories, Sana'a', Yemen

${ }^{3}$ Ministry of Health, Sana'a, Yemen
}

\section{Corresponding Author:}

Mohammed Al Amad, MD

Yemen Field Epidemiology Training Program

Ministry of Public Health and Population

Sana'a

Yemen

Phone: 967770123354

Email: $\underline{\text { mohdalemad@yahoo.com }}$

\section{Abstract}

Background: Bacterial contamination of the intensive care unit (ICU) is one of the risk factors responsible for the high incidence of nosocomial infections that can significantly increase the mortality among ICU patients.

Objective: The aim of this study was to investigate the bacterial contamination and pathogen isolates from the ICU environment of hospitals in Sana'a city, Yemen.

Methods: A descriptive cross-sectional study was performed in Sana'a city hospitals from December 5 to December 15, 2019. All hospitals that frequently reported mortality among ICU patients were included. A sterile swab moistened in sterile normal saline was used for sample collection. Seven ICU sites were targeted, including the patient's bed, bedside table, masks of the oxygen-supplying apparatus, intravenous (IV) stand, door knob, wall, and floor, and two samples from each site were collected. The samples were transported to the National Center of Public Health Laboratory for microbiological culture.

Results: A total of 112 swabs were collected from the ICUs of eight hospitals. Among these, 87 (77.7\%) yielded positive bacterial growth and 109 bacterial strains were isolated, including 62.4\% (n=68) gram-positive and 37.6\% (n=41) gram-negative bacteria. Coagulase-negative Staphylococcus, Staphylococcus aureus, and Bacillus cereus were the predominant gram-positive bacteria isolated, which accounted for $27.5 \%(n=30), 21.1 \%(n=23)$, and $10.1 \%(n=11)$ of all 109 bacterial isolates, respectively. Klebsiella species, Pseudomonas species, and Acinetobacter were the main gram-negative isolates obtained, accounting for $12.8 \%$ $(\mathrm{n}=14), 12.8 \%(\mathrm{n}=14)$, and $11.9 \%(\mathrm{n}=13)$ of all 109 bacterial isolates, respectively. The common contaminated sites were the patients' beds/bedside tables (40/109 strains, 36.7\%), floors (24/109 strains, 22.0\%), walls (15/109 strains, 13.8\%), and masks of the oxygen-supplying apparatus (12/109 strains, 11.0\%). The door knobs and IV stands were contaminated by 9 strains, representing $8.3 \%$ of the total isolated bacteria.

Conclusions: The contamination of ICU environments was high and patients' surroundings were the most contaminated areas. Implementations of strict quality standards of hygienic practices and effective cleaning of inanimate surfaces by the hospitals' infection control units along with periodic monitoring by the health authority are highly recommended.

(iproc 2022;8(1):e36591) doi: 10.2196/36591

\section{KEYWORDS}

bacterial contamination; intensive care units; Yemen 
Edited by Y Khader; this is a non-peer-reviewed article. Submitted 18.01.22; accepted 19.01.22; published 04.02.22.

Please cite as:

Al Amad M, Al Shargabi IA, Nasher S, Al-Haidari SA, Al-Dubaiee R, Moghalles SA, Al Moayad KA

Bacterial Contamination of Intensive Care Units, Sana'a City, Yemen, 2019

iproc 2022;8(1):e36591

URL: https://www.iproc.org/2022/1/e36591

doi: $\underline{10.2196 / 36591}$

PMID:

(CMohammed Al Amad, Intesar Abdulsalam Al Shargabi, Samar Nasher, Sami Ahmed Al-Haidari, Riham Al-Dubaiee, Suaad Ameen Moghalles, Khaled Abdullah Al Moayad. Originally published in Iproceedings (https://www.iproc.org), 04.02.2022. This is an open-access article distributed under the terms of the Creative Commons Attribution License (https://creativecommons.org/licenses/by/4.0/), which permits unrestricted use, distribution, and reproduction in any medium, provided the original work, first published in Iproceedings, is properly cited. The complete bibliographic information, a link to the original publication on https://www.iproc.org/, as well as this copyright and license information must be included. 